\title{
INTENTION TO CONTINUE TO USE MOBILE PRODUCTIVITY APPS
}

\section{INTENÇÃO DE CONTINUIDADE DE USO DE APLICATIVOS MÓVEIS DE PRODUTIVIDADE}

Recebido em 29.02.2020 Aprovado em 01.06.2020

Avaliado pelo sistema double blind review

DOI: https://doi.org/10.12712/rpca.v14i2.40848

\section{Luis Hernan Contreras Pinochet}

luis.hernan@unifesp.br

Departamento Acadêmico de Administração/Universidade Federal de São Paulo - Osasco/São Paulo, Brasil https://orcid.org/0000-0003-2088-5283

\section{Letícia Yoshimi Tanaka}

leticia.tanaka@hotmail.com

Departamento Acadêmico de Administração/Universidade Federal de São Paulo - Osasco/São Paulo, Brasil https://orcid.org/0000-0002-6674-3945

\section{Marcia Carvalho de Azevedo}

marcia.azevedo@,unifesp.br

Departamento Acadêmico de Administração/Universidade Federal de São Paulo - Osasco/São Paulo, Brasil https://orcid.org/0000-0002-8368-9637

\section{Evandro Luiz Lopes}

elldijo@uol.com.br

Departamento Acadêmico de Administração/Universidade Federal de São Paulo - Osasco/São Paulo, Brasil Programa de Pós-graduação em Administração/(PPGA) Universidade Nove de Julho - São Paulo/São Paulo, Brasil https://orcid.org/0000-0002-2780-4215

\begin{abstract}
The aim of this article is to understand the role of user value perspectives (perceived utility and perceived pleasure) in the intention to continue to use mobile productivity applications. The proposed model was developed based on data collected in a survey with 320 respondents. A Multivariate of Structural Equations Modeling was used. The results validate the model and confirm that the selected constructs have considerable explanatory power. It was understood that, in productivity apps, the hedonic characteristic should be observed carefully, and that this type of app has greater identification with perceived utility characteristics and confirmation of expectations, by its very nature.
\end{abstract}

Keywords: Mobile applications. Productivity apps. Value perspective. Intention to continue to use.

\section{Resumo}

O objetivo deste artigo é entender o papel das perspectivas de valor do usuário (utilidade percebida e prazer percebido) na intenção de continuar usando aplicativos móveis de produtividade. O modelo proposto foi desenvolvido com base nos dados coletados em uma pesquisa com 320 entrevistados. Foi utilizada uma modelagem multivariada de equações estruturais. Os resultados validaram o modelo e confirmaram que as relações possuem um poder explicativo considerável. Conclui-se que, em aplicativos de produtividade, a característica hedônica deve ser observada com cuidado e que esse tipo de aplicativo tem maior identificação com características de utilidade percebida e conformação de expectativas, por sua própria natureza.

Palavras-chave: Aplicativos móveis. Aplicativos de produtividade. Perspectiva de valor. Intenção de continuar utilizando. 


\section{Introduction}

Mobile devices promote not only entertainment, but also productivity through mobile applications that perform tasks for users (Islam, Low, \& Hasan, 2013). Mobile productivity apps have become personal assistants, offering the users a variety of tools that help them to carry out daily tasks. The tools available are very diverse, such as notebook, online calendar, task lists, expense management, exercise and food monitoring, among others. In this way, individuals can improve and facilitate their routine through the use of applications (Azfar, Choo, \& Liu, 2016; Bertschek \& Nieble, 2016).

Smartphones, tablets and smartwatches have become indispensable devices for modern society when it comes to technologies associated with mobile devices (Arruda Filho, Cabusas, \& Dholakia, 2010). According to a report by Statista (2018), in 2017, the number of downloads of mobile applications was 197 billion. The projection for 2020 is to generate 188.9 billion dollars of revenue in app stores and inapp advertising. In 2010, an In-Stat survey said that entertainment apps were the most downloaded, but productivity apps were the ones that generated the most revenue, representing about $59 \%$ of all mobile app revenue.

Understanding the value of the product or service from the users' perspective has been recognized as a successful strategy and is often linked to business performance. In addition, increased productivity is seen as essential for economic, social and cultural development in different countries. It is observed, therefore, that the study's contribution can be both managerial for companies and application developers, as well as social, economic and cultural, for society in general, given the importance of productivity and the fact that the use of technology associated with mobile applications is increasing (DeSarbo, Jedidi, \& Sinha, 2001; Voropanova, 2015).

In view of the relevance of the use of applications to increase productivity, it is proposed to study the intention to continue to use productivity applications. For the development of the theoretical model, the Hsiao, Chang, and Tang (2016) model of social mobile applications and the Bhattacherjee (2001) Information Systems Expectation-Confirmation Model were used. In the light of these models, a new model was developed in which consumers' value perspectives (utilitarian and hedonic) were emphasized. Altogether, six constructs were selected and analyzed: Perceived Utility, Perceived Pleasure, Satisfaction, Habit, Confirmation and Intention to Continue to Use.

This study aims to benefit mobile application developers and companies and, at the same time, enrich the literature, since there are few specific works related to the theme in international databases (Chou \& Hsu, 2016; Hsiao et al., 2016; Hsu \& Lin, 2016; Shiau \& Luo, 2013). The present study is relevant to provide an understanding of which variables should be observed and focused by developers, as well as to comprehend and predict user behavior considering the interaction between utility and hedonic characteristics in mobile applications.

Given the context presented, the article aims to understand the role of user value perspectives (perceived utility and perceived pleasure) in the intention to continue to use mobile productivity applications.

The article is structured in the following sections, introduction that presents the contextualization, conceptual framework, with theoretical constructs, theoretical model and formulated hypotheses, then the development of the methodological aspects of the research is explained, and the last two sections present results and conclusions. 


\section{Conceptual framework}

This section aims to present the fundamental concepts of this study, which are consumer value perspectives, and hedonic value versus utility value.

\section{Consumer value perspectives}

One area that has recently become a focus of great interest in the marketing literature has been the study of consumption values (Lee \& Overby, 2004). According to Babin, Darden, and Griffin (1994), the literature review does not present a precise and unique definition of value. The concept of value may vary, depending on the context of the study (Holbrook \& Corfman, 1985).

The value for the customer is no longer only due to the products and services themselves, but also by what is created during the interaction and consumption experience, where the consumption value is generated as a result of the consumption experience; and, consumer satisfaction is the result of the consumption value that was generated (Voropanova, 2015).

Consumer's value has been recognized as an important predictor of consumer's purchase decision (H. W. Kim, Chan, \& Gupta, 2007). It is derived from everyone's experience and interaction with a product or service (Turel, Serenko, \& Bontis, 2010). Consumer values can also be considered motivators for the intention to use and continuance usage behaviors (Chiu, Wang, Fang, \& Huang, 2014).

According to Turel et al. (2010), consumer value derives from the individual's experience and interaction with a certain product or service and is considered an important predictor of the purchase decision in the marketing and e-commerce literature. Zeithaml (1988) identifies four definitions for the term "value": 1) price; 2) trade-off between costs and benefits; 3) trade-off between perceived product quality and price and 4) global assessment of subjective values, considering all relevant assessment criteria. According to the author, in this definition the value is expressed by the complete consumption experience, and not simply by the purchase of the product or service. The values that will be investigated in this study are those related to motivations and evaluations of the consumption experience in a service.

Consumer value can be divided into utilitarian and hedonic value (Pöyry, Parvinen, \& Malmivaara, 2013). In the present study, utility value and hedonic value will be associated with constructs as perceived utility and perceived pleasure, respectively.

\section{Utility value versus hedonic value}

Consumer behavior is associated with hedonic and utilitarian aspects. The first is related to the emotion that the consumer has when using or buying the product, while the second is related to the utility that the product has for the consumer. Authors such as Bardhi and Arnould (2005) and M. Jones, Reynolds, and Arnold (2006) agree that in a shopping experience, utilitarian and hedonic consumption can coexist. Even in the case of different values, it is understood that they are not excludent, they only address different characteristics.

Utilitarian purchase is characterized by rationality, refers to rational, objective and economic aspects, such as the search for the lowest price and the highest quality (Andersson \& Engelberg, 2006), while hedonic is focused on psychological, symbolic and emotional consumption characteristics (Hernandez, 2009). The utilitarian meaning of a purchase is based on factors such as its utility, efficiency, convenience or product value in exchange currency in the traditional sense of economy (Allen $\& \mathrm{Ng}, 1999$ ).

Several authors such as Babin et al. (1994) and Andersson and Engelberg (2006) analyze consumption through a dichotomous vision, that is, in addition to identifying the rational, utilitarian perspective, they also explain the concept of consumption from a hedonic, emotional perspective, of purchase for pleasure, even if they often use different terminologies. For the authors this view of consumption, the hedonic, is 
completely different from the utilitarian view, because it is motivated by multisensory, emotional aspects and fantasies of the consumer. According to these authors, this type of consumption is related to the value perceived by the consumer of the shopping experience, that is, subjective factors that vary according to the context of each one.

Just as products have their hedonic and utilitarian intrinsic values, theoretically consumers could also develop different levels of hedonic and utilitarian purchase values from a shopping experience (Holbrook \& Hirschman, 1982). In general, the hedonic value of products is relevant to the affective, experimental and symbolic domains of consumption because it elicits pleasure and excitement while the utilitarian value of products is primarily goal-oriented (Batra \& Ahtola, 1991; Mano \& Oliver, 1993).

According to the theory of motivation, perceptions of utility are related to extrinsic motivation, while perceptions of hedonic value are related to intrinsic motivation (Zanna \& Rempel, 1988). Extrinsic motivation emphasizes the behavior of achieving a certain goal or reward, while intrinsic motivation refers to the pleasure derived from a certain behavior. Therefore, utility value and hedonic value are proposed in the present study as factors that impact the intention to continue to use.

\section{Construction of the theoretical model and hypotheses}

For the construction of the theoretical model, the Hsiao et al. (2016) model of Post-Acceptance Continuance Usage of Information Systems (IS) was used, from which the variable Social Ties was excluded, given its inadequacy for the present study. The following constructs were used: Satisfaction, Habit, Perceived Utility, Perceived Pleasure, Confirmation and Intention to Continue to Use. In conjunction with this model, the Confirmation construct was also used, based on the Bhattacherjee (2001) Expectation-Confirmation Model (ECM).

\section{Satisfaction}

In the present study, satisfaction is defined as the overall assessment based on the total experience of buying and consuming a commodity over time (Anderson, Fornell, \& Lehmann, 1994), that is, the perception of consumers in the continuous use of productivity applications.

In the Bhattacherjee (2001) model, the intention of continuance usage of users is determined by the satisfaction and utility perceived in continuous use. The author argues that users with higher levels of satisfaction have intention to use in a more intense way in an online context.

Satisfaction along with continuous use is seen as a key in maintaining consumer loyalty, considered as an affective response to the gap between expectation and perceived performance after consumption. The direct relationship between satisfaction and continuity of use is the basis of the model and has been empirically validated. In addition, many studies in the marketing area suggest that user satisfaction is a predictor of intention to continue to use information technology (Thong, Hong, \& Tam, 2006). Previous studies of mobile services have also supported the argument that user satisfaction is positively related to post-purchase continuance usage intention (Hee-Woong Kim, Gupta, \& Koh, 2011).

In addition to the effect of habit on the intention to continue using productivity apps, we also postulate that habit is significantly influenced by satisfaction. Limayem, Hirt, and Cheung (2007) in their comprehensive definition, application and analysis found support for the relationship between satisfaction and habit. Besides that, based on the study by Limayem et al. (2007), the influence of satisfaction on habit has also been proven in microblogging and instant messaging services research (Barnes, 2011; Luo \& Lee, 2015). Therefore, the following hypotheses were formulated:

Hypothesis 1a: Satisfaction positively influences the intention to continue using productivity apps.

Hypothesis 1b: Satisfaction positively influences the habit of using productivity apps. 


\section{Habit}

Habit is defined by Verplanken and Wood (2006) as learning sequences of acts that become automatic responses to specific situations. In the present study, habit, within the context of productivity applications, is the tendency of users to automatically access applications without thinking (Chou \& Hsu, 2016; S. S. Kim, Malhotra, \& Narasimhan, 2005). S. S. Kim and Malhotra (2005) suggest that habit can produce favorable feelings regarding behavior, thus it can increase the intention to continue to use. Marketing literature also says that habit is a great predictor of customer loyalty or intention to repeat purchase (Rauyruen, Miller, \& Groth, 2009).

Intention and habit are considered the most important antecedents of behavior, however, the understanding of the nature of the relationship between habit, intention and behavior has been controversial (Limayem \& Hirt, 2003; Bhattacherjee, Limayem, \& Cheung, 2012; Limayem \& Hirt, 2003). Habit can have both a direct and interactive effect on behavior. In this research, the habit was adopted as an antecedent of intention (Barnes, 2011).

Other studies argue that habit conceptually overlaps intention, providing additional explanatory power in relation to continuous use (Chou \& Hsu, 2016; Limayem et al., 2007). M. A. Jones, Mothersbaugh, and Beatty (2002) support the idea that the more usual the behavior, the greater the perceived effort to change behavior, because any intention to change behavior would require more information and greater effort, which would result in possible loss of benefits. Thus, it is understood that:

Hypothesis 2: Habit positively influences the intention to continue using productivity apps.

\section{Perceived utility}

Perceived utility is the result of the evaluation that occurs in relation to the acquisition of a product or service, it is based more on a task-oriented and less on an emotional perspective (Babin et al., 1994; Holbrook \& Hirschman, 1982). The goal of an utility information system is to increase performance while encouraging efficiency. Therefore, utility systems provide instrumental and productivity-oriented value for users.

Based on an utilitarian vision, the Bhattacherjee (2001) model includes utility perceived as a variable that influences the intention to use. Davis (1989) characterizes it as a degree of perception in which the individual believes that the use of a specific service or system improves his performance. Also, Babin et al. (1994) proposed that perceived utility should influence consumer satisfaction and empirically showed strong correlations between perceived value and satisfaction. Consequently:

Hypothesis 3a: Perceived utility positively influences satisfaction of using productivity apps.

Perceived utility is defined as the degree to which the individual believes that using an application increases his performance. Utility can also be associated with an individual's perception that reproducing a behavior will enable him to gain specific rewards. Previous experiences play an important role in building the intention to continue to use (Dorsch, Grove, \& Darden, 2000). Rogers (1995) explained that such experiences reduce uncertainty and help to obtain information in high-tech services as habit refers to an automatic behavior resulting from learning (Limayem et al., 2007). Davis' Technology Acceptance Model (TAM) (1989) suggests that individuals accept technology if they believe in their positive performance, and as a result they increase the tendency to use it frequently. So:

Hypothesis 3b: Perceived utility positively influences the habit of using productivity apps.

Perceived utility refers to the probability that technology will increase performance, therefore, utility instrumentalizes the rational decision to use it. Bhattacherjee (2001) model, focus on the explanation of 
user intent, especially the post-acceptance variables. Perceived utility is considered an adequate expectation in the context of continuance usage intention (Hsiao et al., 2016). Consequently:

Hypothesis 3c: Perceived utility positively influences the intention to continue to use productivity apps.

\section{Perceived pleasure}

In the present study, perceived pleasure is defined as the degree to which the user feels pleasure using a technology, in this case, productivity applications. Literature on consumer behavior shows that the hedonic value influences the intention of continued use and satisfaction with products and services. For Brown and Venkatesh (2005), the variable has played an important role in determining the acceptance and use of technologies. If an individual evaluates his experience of use positively, it is likely that the same consumption behavior will be repeated. The user perceived pleasure increases the tendency to repeat the action, and this act occurs without a conscious decision and is understood as a habit. Thus, it is assumed that:

Hypothesis 4a: Perceived pleasure positively influences the habit of using productivity apps.

Individuals often seek sensory stimuli, and mobile applications can provide multisensory experiences (Van Der Heijden, 2004) and generate favorable feelings that will lead to a higher degree of satisfaction and intention to continue to use them. The goal of developers is to maximize user's pleasure while using the technology (Childers, Carr, Peck, \& Carson, 2001). These fun and pleasurable experiences will evoke positive feelings that will lead to a degree of satisfaction. User satisfaction is understood as the affective reactions of individuals when using productivity applications. It is inferred that:

Hypothesis 4b: Perceived pleasure positively influences satisfaction in relation to the use of productivity apps.

According to Holbrook and Hirschman (1982), many human behaviors seek pleasure. Perceived pleasure represents an intrinsic type of motivation and in several studies the significance of intrinsic motivation in continuous use has been confirmed. In addition, the consumer literature supports the argument that the intention of continued use is driven by hedonic values (Bauer, Reichardt, Barnes, \& Neumann, 2005; Hsiao et al., 2016). Therefore, it is postulated that:

Hypothesis 4c: Perceived pleasure positively influences the intention to continue to use productivity apps.

\section{Confirmation}

The confirmation construct is understood as confirmation of initial expectations about productivity applications during its use. In the present study, Bhattacherjee (2001) Expectation-Confirmation model (ECM) was used, which was formulated based on the theory that expectations and perceived performance lead to satisfaction and influence the intention to continue using productivity apps (Oliver, 1999).

Several studies have shown the model's validity in a wide range of information technology products and services (Baker-Eveleth \& Stone, 2015; Chen, Chen, Lin, \& Chen, 2011; Vatanasombut, Igbaria, Stylianou, \& Rodgers, 2008). Bhattacherjee (2001) empirically verified the validity of the model in a survey of online users of bank services. The results illustrated that the intention of continuity was determined by satisfaction with the service and the perceived utility in continuous use. In addition, the confirmation construct played a critical role influencing perceived utility and satisfaction.

Before installing an application, the user develops expectations about it. After using it, the user has experiences and develops insights about its performance. This results in the confirmation or disconfirmation of expectations that existed prior to use. In turn, the level of user satisfaction with the 
application is determined by this confirmation. This study also investigated the perceived pleasure dimension, since mobile application users use them for various reasons, not only utilitarian motives (Hsu \& Lin, 2016).

Thong et al. (2006) also proposed the perceived pleasure variable to study the intention to continue using mobile internet services and it was observed that the extent of pleasure perceived in the ECM model allowed a better understanding of continued use behavior. Based on these studies, the following hypotheses are presented:

Hypothesis 5a: Confirmation positively influences the perceived utility of using productivity apps.

Hypothesis 5b: Confirmation positively influences the perceived pleasure of using productivity apps.

Hypothesis 5b: Confirmation positively influences the satisfaction of using productivity apps.

\section{Method}

The approach of this research was quantitative, using an online data collection tool in which structured questions were presented to respondents. With this, our data collection strategy can be classified as an online survey (Malhotra, 2014). The research instrument was translated and adapted to the Brazilian context. The next step was to validate the translation and adaptation of the instrument with two business undergraduate students. Based on their feedback some items were changed.

The data collection method was convenience sampling, a non-probabilistic technique, a fact that limits the generalization of research results (Malhotra, 2014). To measure each item of the constructs, the Likert-type scale was used with end points anchored in "totally disagree" (1) and "totally agree" (7) for all 47 statements. Objective questions were elaborated for aspects such as gender, educational level and family income of the respondent. Two additional questions were also included in the instrument with the objective to better understand the use of each category of app separately. Both of them used the Likert scale also with 7 points, one was about the frequency of use and the other one about the utility of each app category.

The questionnaire was made available on the Google Forms platform and disseminated on social networks, on email distribution lists and posters - the latter with QR code and shortened URL availability, in order to facilitate the respondent's access to the questionnaire.

After applying the survey, a total of 350 questionnaires was obtained and tabulated in Microsoft Excel. Of the 350 respondents, 333 considered themselves users of productivity applications. Thus, in a first stage, 17 questionnaires were eliminated.

In a second stage, the database was consolidated, in which the questionnaires whose respondents had used a maximum of three different points on the Likert scale in all answers were considered outliers and then excluded. The use of only three points interferes with the interpretation of statistical validation tests. Respondents who use one to three points on the scale to answer all responses did not attempt to discriminate values, so their responses do not reflect their current priorities. Duplicated questionnaires with invalid objective responses were also disregarded. This process eliminated 13 questionnaires, leaving a total of 320 valid observations remaining in the final sample.

In this research, $G^{*}$ power 3.1.9 software was used to calculate a priori the number of questionnaires needed to validate the test, which should maintain at least $80 \%$ of the observed power to ensure the validity of the applied model. For this study, the variable "intention to continue to use" was tested because it received the largest number of independent variables linked to it within the model. In all, there were four calls. In the test for "a priori" the following parameters used were: effect size $f^{2}$ equal to 0.15 and test power equal to 0.80, indicated by Hair, Hult, Tomas, Ringle, and Sarstedt (2010), and p<0.05, 
the result is a critical $\mathrm{F}$ of 2.48 with a minimum sample of 85 individuals. In the post hoc test, a sample of 320 individuals was used, the effect size of $\mathrm{f}^{2}$ equal to 0.15 and 4 predictors, the results were: Critical F 2.40, the test power (1-b err prob) is equal to $99.99 \%$.

The sample size for the pre-test should have a minimum of 4 and a maximum of 30 individuals (Hair et al., 2010). For this study, the pre-test was carried out with 25 individuals to verify whether there was an understanding of the research instrument.

\section{Presentation of Results}

This section deals with the presentation and analysis of results: mapping of the main productivity applications, profile of respondents, analysis of difference in group means, and analysis of structural model.

\section{Mapping key productivity applications}

For the present study, a mapping of the main productivity applications in the market was carried out. Applications with more than 1 million downloads were considered relevant. From this initial selection, the applications were divided into 5 categories, based on the existing subsections on Google Play, which are: 1) Health and well-being, 2) Personal organization, 3) Finance, 4) Academic and 5) Professional. Each category had ten applications and the respondents were instructed to indicate which ones they had already used and had the option to indicate other productivity applications they used but were not listed.

The applications of each category can be seen in Tables 1, 2, 3, 4 and 5. All applications were compatible with Android and iOS platforms. The tables have the descriptions of each application and number of downloads, taken from Google Play in 2019.

\begin{tabular}{lll}
\hline Table 1 & & \\
Health and Well-being Apps & & Downloads \\
\hline App & Objective & $50 \mathrm{MM}$ \\
\hline Runtastic & Monitor progress and physical activity goals & $10 \mathrm{MM}$ \\
Nike Run Club & Monitor progress for running and walking & $10 \mathrm{MM}$ \\
Noom & Lose weight through nutritional feedback, pedometer & $10 \mathrm{MM}$ \\
FatSecret & Count calories, track meal, exercise and weight & $10 \mathrm{MM}$ \\
Lifesum & Count calories and monitor food by barcode & $10 \mathrm{MM}$ \\
Meu orientador de dieta & Break bad habits and create eating routines & $10 \mathrm{MM}$ \\
Calm & Guide meditation, sleep and anxiety aid & $10 \mathrm{MM}$ \\
Fitness e Musculação & Monitor bodybuilding training & $10 \mathrm{MM}$ \\
RunKeeper & Monitor physical activity with statistics and progress & $10 \mathrm{MM}$ \\
Lembrete de beber água & Remind and record water intake & \\
\hline
\end{tabular}

Note. Number of downloads taken from Google Play (2019).

\begin{tabular}{lll}
\hline \multicolumn{2}{l}{ Table 2} & \\
Personal Organization & Apps & \\
\hline App & Objective & Downloads \\
\hline Google Agenda & Insert events, tasks and goals in the calendar & $1 \mathrm{~B}$ \\
Google Drive & Storage and organize cloud file & $1 \mathrm{~B}$ \\
Microsoft One Note & Digital notepad & $500 \mathrm{MM}$ \\
Google Keep & Notepad and reminders & $500 \mathrm{MM}$ \\
Evernote & Digital notepad & $100 \mathrm{MM}$ \\
Todoist & Track tasks and projects & $10 \mathrm{MM}$ \\
Any.do & Task list, calendar and reminder & $10 \mathrm{MM}$ \\
Habitica & Gamification with routine tasks & $1 \mathrm{MM}$ \\
Mindly & Structure thoughts and notepad & $1 \mathrm{MM}$ \\
TimeTree & Shared calendar & $1 \mathrm{MM}$ \\
\hline
\end{tabular}

Note. Number of downloads taken from Google Play (2019). 


\section{Luis Hernan Contreras Pinochet, Letícia Yoshimi Tanaka, Marcia Carvalho de Azevedo e Evandro Luiz Lopes}

\begin{tabular}{lll}
\hline $\begin{array}{l}\text { Table } 3 \\
\text { Finance Apps }\end{array}$ & \\
\hline App & Objective & Downloads \\
\hline Money Manager & Manage personal accounts & $5 \mathrm{MM}$ \\
Money Lover & Manage expenses and budget & $5 \mathrm{MM}$ \\
Monefy & Manage money & $5 \mathrm{MM}$ \\
Mobills & Control personal finances & $5 \mathrm{MM}$ \\
Expense Tracker & Manage finance activity and expense savings & $1 \mathrm{MM}$ \\
Wallet & Manage budget & $1 \mathrm{MM}$ \\
1Money & Monitor and manage expenses & $1 \mathrm{MM}$ \\
Organizze & Control monthly expenses & $1 \mathrm{MM}$ \\
Minhas Economias & Create budget and plan expenses & $1 \mathrm{MM}$ \\
Orçamento Fácil & Manage expenses & $1 \mathrm{MM}$ \\
\hline
\end{tabular}

Note. Number of downloads taken from Google Play (2019).

\begin{tabular}{lll}
\hline $\begin{array}{l}\text { Table } 4 \\
\text { Academic Apps }\end{array}$ & \\
\hline App & Objective & Downloads \\
\hline Google Drive & Storage and organize files in cloud & $1 \mathrm{~B}$ \\
Dropbox & Storage and organize files in cloud & $500 \mathrm{MM}$ \\
Microsoft One Note & Digital notepad & $500 \mathrm{MM}$ \\
Evernote & Digital notepad & $100 \mathrm{MM}$ \\
Todoist & Track tasks and projects & $10 \mathrm{MM}$ \\
Any.do & Task list, calendar and reminder & $10 \mathrm{MM}$ \\
busuu & Learn languages & $10 \mathrm{MM}$ \\
Trello & Manage projects & $5 \mathrm{MM}$ \\
Forest & Maintain concentration & $5 \mathrm{MM}$ \\
Scanbot & Organize and scan documents & $1 \mathrm{MM}$ \\
\hline
\end{tabular}

Note. Number of downloads taken from Google Play (2019).

\begin{tabular}{lll}
\hline $\begin{array}{l}\text { Table } 5 \\
\text { Professional Apps }\end{array}$ & & \\
\hline App & Objective & Downloads \\
\hline Google Drive & Storage and organize files in cloud & $1 \mathrm{~B}$ \\
Dropbox & Storage and organize files in cloud & $500 \mathrm{MM}$ \\
Slack & Team communication and collaboration & $100 \mathrm{MM}$ \\
Collect & Send documents and storage content & $10 \mathrm{MM}$ \\
Trello & Project management & $5 \mathrm{MM}$ \\
Asana & Organize and manage team projects & $1 \mathrm{MM}$ \\
Microsoft Teams & Teamwork hub & $1 \mathrm{MM}$ \\
Scanbot & Organize and scan documents & $1 \mathrm{MM}$ \\
Adobe Fill \& Sign & Fill out, sign and send forms directly from your phone or tablet & $1 \mathrm{MM}$ \\
Google Toggl & Task and project timesheet & $100 \mathrm{~K}$ \\
\hline
\end{tabular}

Note. Number of downloads taken from Google Play (2019).

In the Health and Wellbeing category, we used the applications Runtastic, Nike Run Club, Noom, FatSecret, Lifesum, My Diet Advisor, Calm, Fitness and Bodybuilding, RunKeeper and Water Drink Reminder. Of these, the most used apps were the Water Drink Reminder (27.8\%), Nike Run Club (25.1\%) and Calm (24.2\%).

Of the apps that were not listed, the ones that had the most impact were similar and also competitors from the ones of the selection, they are: apps for mapping physical exercises, weight loss and meditation/mental health. In addition, applications such as Clue, My Pill and Menstrual Cycle Calendar were mentioned in the open responses. They are specific to the female audience and for this reason, were not considered in the selection of the present study. These applications map menstrual cycle, ovulation and use of birth control pills, based on user information inputs. 
In the Personal Organization category, Todoist, Evernote, Any.do, Microsoft One Note, Google Keep, Habitica, Google Calendar, Google Drive, Mindly and TimeTree were considered. About 91\% of respondents use Google Drive and 72.5\% Google Calendar. One of the possible reasons for high adherence may be the fact that these applications are already installed on most smartphones. Another app that stood out was Evernote, with $40 \%$ of users among respondents. Of the applications that were not listed, the ones that were the most mentioned were applications with similar objectives to those of selection, like cloud organization of documents and notepad.

In the Finance category, the applications considered were: Money Manager, Expense Tracker, Wallet, 1Money, Organizze, My Savings, Easy Budget, Monefy and Mobills. Of these, the most used were Mobills $(14.6 \%)$, Organizze $(13.4 \%)$ and Wallet (10.1\%). Interestingly, in this category, the Nubank and Itaú applications for banking services were considered as productivity applications by respondents. This was probably due to the recognized usability of these applications and the possibility of seeing all expenses related to the cards of their respective banks in an easy and visual way, serving as financial control.

In the Academic category: Todoist, Evernote, Trello, Any.do, busuu, Scanbot; Microsoft One Note, Forest, Dropbox and Google Drive were considered. Of this category, Google Drive is used by $86.6 \%$ of respondents, followed by Dropbox (57.6\%) and Trello (32.5\%). Of the applications that were not part of the selection, Duolingo, an application for language learning, was the most suggested among respondents.

In the Professional category, the applications considered were: Asana, Slack, Trello, Microsfot Teams, Google Drive, Scanbot, Adobe Fill \& Sign, Toggl, Dropbox and Collect. The most used of them were Dropbox (49.6\%), Google Sheet (49.6\%) and Trello (33.7\%). Of the applications that were not part of the selection, Google Hangouts and Jira were also mentioned. Approximately 55\% of respondents indicated that they were interested in installing some of the listed applications that they haven't used yet, showing intention to use.

\section{Respondents profile}

The profile of the survey respondents is presented in this section. In Table 6, information about sex, age, family income, exercise of professional activity and educational level is detailed.

\begin{tabular}{llll}
\hline Table 6 & & & \\
Sample Characteristics & & $\mathbf{n}$ & $\mathbf{\%}$ \\
\hline \multirow{2}{*}{ Gender } & Male & 93 & 29.1 \\
& Female & 227 & 70.9 \\
\hline \multirow{5}{*}{ Education } & Incomplete high school & 1 & 0.3 \\
& High school completed & 17 & 5.3 \\
& Undergraduate student & 172 & 53.8 \\
& Graduate degree & 82 & 25.6 \\
& Graduate student & 12 & 3.8 \\
& Postgraduate degree & 36 & 11.3 \\
\hline \multirow{5}{*}{ Family income } & Less than 4 minimum wages & 89 & 27.8 \\
& From 4 to 6 minimum wages & 94 & 29.4 \\
& From 7 to 10 minimum wages & 66 & 20.6 \\
Engaged in professional activity & Mes than 10 minimum wages & 71 & 22.2 \\
& No & 207 & 64.7 \\
& Up to 25 years old & 113 & 35.3 \\
\hline \multirow{2}{*}{ Age } & Between 26 and 35 years old & 80 & 65.3 \\
& Between 36 and 45 years old & 13 & 4.1 \\
& Above 45 years old & 18 & 5.6 \\
\hline & Total & 320 & 100 \\
\hline
\end{tabular}


It was found that more than half of the respondents declared themselves to be female $(70.9 \% / \mathrm{n}=227)$, the number of male individuals in the sample was about $1 / 3$ of the respondents $(29.1 \% / n=93)$. It must be considered that there are specific applications for the female audience, in which the objective, interface and language are aimed at women.

With regard to education, more than half of the respondents are attending undergraduate courses $(53.8 \% / \mathrm{n}=172)$. It is noticed that the users of productivity applications in the sample, mostly, have access to information and have a high level of education. It was also observed that the majority of respondents are inserted in the labor market, since $64.7 \%$ have professional activity $(64.7 \% / \mathrm{n}=207)$.

Regarding the income of the respondents, there was a predominance of individuals with incomes of 4 to 6 minimum wages $(29.4 \% / n=94)$ and with income bellow 4 minimum wages $(27.8 \% n=89)$. A significant percentage of men are concentrated in income greater than 10 minimum wages $(35.5 \% / \mathrm{n}=33)$, while females are concentrated in lower incomes, less than $4(32.2 \% / \mathrm{n}=73)$ and 4 to 6 minimum wages $(32.2 \% / \mathrm{n}=73)$.

Users of productivity applications in the sample are mostly concentrated in the age group up to 25 years $(65.3 \% / n=209)$, followed by the age group between 26 and 35 years $(25 \% / n=80)$. However, the numbers presented in the other age groups are interesting, like the age group above 46 years $(5.6 \% / \mathrm{n}=18)$ in which the incidence was higher than the previous group of 36 to 45 years $(4.1 \% / n=13)$.

Among those who identified themselves as users $(95.1 \% / \mathrm{n}=350)$, the vast majority $(97.2 \% / \mathrm{n}=311)$ uses productivity apps through the smartphone, followed by the smartwatch $(2.2 \% / \mathrm{n}=7)$ and Tablet $(0.6 \% / n=2)$. When asked about which platform they used, more than half $(63.8 \% / n=204)$ replied that they used the Android operating system and the others, the iOS platform $(36.3 \% / \mathrm{n}=116)$.

Android users are concentrated in incomes below $4(31.9 \% / \mathrm{n}=65)$, while those of iOS in incomes of 4 to 6 minimum wages $(33.6 \% / \mathrm{n}=39)$. The distribution of smartphone use between different incomes levels does not have great differences, being slightly more concentrated in the lower incomes. It is observed, however, that the use of tablet and smartwatch is concentrated in the highest incomes.

\section{Analysis of the difference of groups means}

The average consumption per week in minutes $\left(\bar{x}_{\text {total }}=403.75\right.$ - equivalent to 6.72 hours per week) was calculated. This average was used to divide the sample in two distinct groups of consumption time, below this value the "low" group, and above the "high" group. The average was calculated separately for each one of the five categories. It was possible to observe that there were no statistical differences presented by the $t$ tests (analysis of means in independent samples) in the behavior of the low and high frequency groups in the degree of utility. This means that user behavior is very similar across all categories of apps.

Two other intergroup analyzes had the gender variable (male and female) as a driver, given the respective average consumption time and degree of utility in each category of productivity applications. Intergroup analysis of the average degree of utility of the Health and Well-being, Personal Organization, Finance, Academic and Professional categories, for the male and female groups, is shown in Figure 1. 


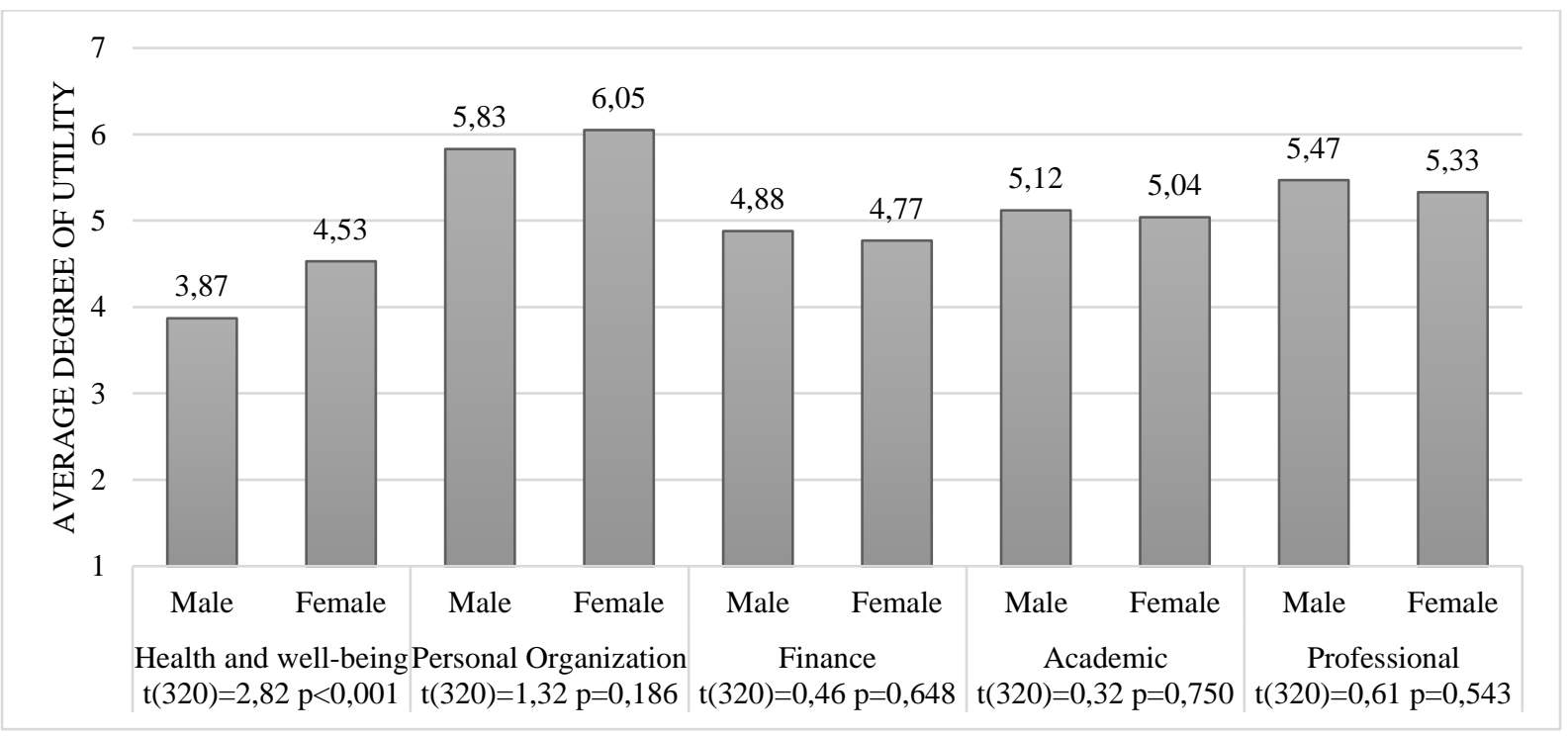

Figure 1 - Aggregate average of the degree of utility of mobile productivity applications

Looking at consumption time, the female group had the highest average in the health and well-being category. This result is aligned with the literature focused on understanding gender differences, in relation with health care and well-being, which indicates that women are more likely than men to adopt disease prevention practices (Bertolini \& Simonetti, 2014). The use of apps in the health and wellness category has the potential to support and promote behaviors that prevent health problems. The other categories showed no difference between the averages of consumption time among men and women. The intergroup analysis of the average consumption time in the categories Health and Well-Being, Personal Organization, Finance, Academic and Professional for the male and female groups is presented in Figure 2.

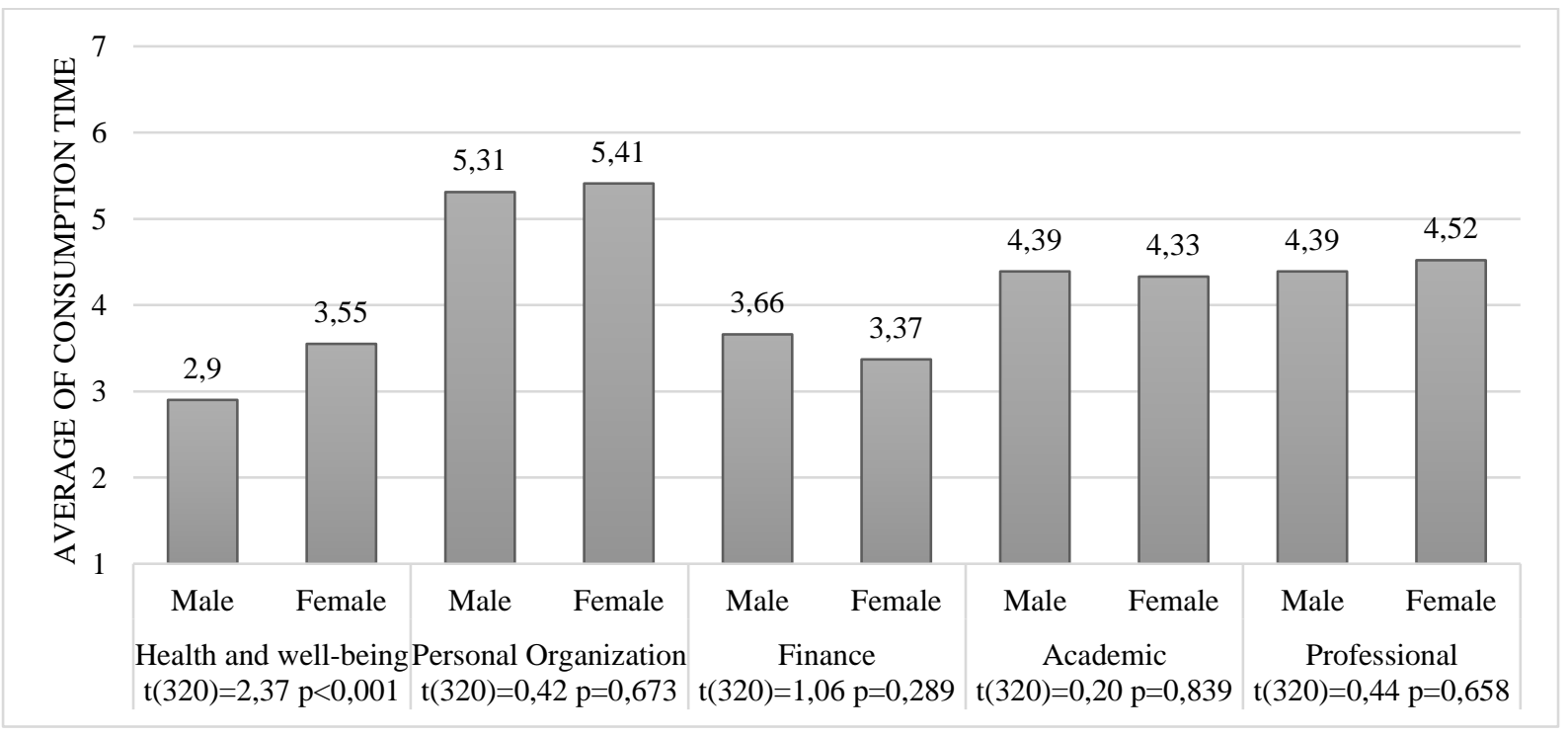

Figure 2 - Aggregated average of consumption time of mobile productivity apps

The consumption time per week of productivity applications is greater for males. While the average consumption for men is 432 minutes per week, about 7 hours a week, the average consumption for women is 391 minutes, representing 6.5 hours a week. 


\section{Analysis of structural model}

Both the initial analyses of the database and the modeling of structural equations themselves followed the recommendations of Ringle, Silva and Bido (2015). Even if this technique of data analysis is on the rise in applied social sciences (Hair et al., 2014), a preliminary reading of its assumptions may be interesting to beginners in multivariate data analysis.

The normality of the data was verified by the Kolmogorov-Smirnov test (K-S) and the respective p-value of each variable. This procedure was necessary to limit the possibility of using some statistical analysis techniques that have the normal data distribution as a characteristic. All individual $\mathrm{Z}$ and $\mathrm{p}$-value values of the K-S test for indicators resulted in $\mathrm{p}<0.001$ as shown in Appendix A (Hair, Hult, Tomas, Ringle, \& Sarstedt, 2014). Regarding the predictive variables related to the latent variable "intention to continue to use", it was possible to accommodate multicollinearity in the model - all values of Variance Inflation Factors (VIFs) were below 5, the lowest being 1.078 and the highest 2.526.

After the first interaction, the results of the factorial loads obtained by the variables were presented and none of the factorial loads were less than 0.5 . Thus, it was not necessary to exclude variables. Following the discriminant validity was verified, which involves the correlation between the constructs of the theoretical model and the convergent validity. This correlation demonstrates the extent to which the latent variable correlates with the chosen items.

Discriminating validity evaluated items that reflect the factor or that are correlated with other factors. In this research, the average variances extracted were higher or equal to the square of the correlation between factors, as presented in Table 7, with the definitive Fornell-Larcker criterion with all the factorial loads of each indicator with values above 0.5. It was not necessary to exclude variables for model adjustment.

Table 7

Discriminant V alidity

\begin{tabular}{lllllllll}
\hline & $(1)$ & $(2)$ & $(3)$ & $(4)$ & $(5)$ & $(6)$ \\
\hline (1) Confirmation & $\mathbf{0 . 8 1 1}$ & & & & & \\
(2) Habit & 0.511 & $\mathbf{0 . 8 1 4}$ & & & & \\
(3) Intention to Continue to Use & 0.652 & 0.656 & $\mathbf{0 . 8 4 7}$ & & & \\
(4) Perceived Pleasure & 0.457 & 0.480 & 0.556 & $\mathbf{0 . 7 6 2}$ & & \\
(5) Satisfaction & 0.776 & 0.594 & 0.763 & 0.497 & $\mathbf{0 . 8 5 6}$ & \\
(6) Perceived Utility & 0.563 & 0.568 & 0.710 & 0.525 & 0.641 & $\mathbf{0 . 7 5 2}$ \\
\hline
\end{tabular}

Note: The highlighted diagonal presents the square roots of the AVE (Average Variance Extracted).

The analysis of the measurement model must precede the analysis of the relationships between the constructs or latent variables. The next step was to examine the measurement model, which involved: cronbach's alpha, composite reliability, average variance extracted, determination coefficients $\left(\mathrm{R}^{2}\right)$, predictive relevance $\left(\mathrm{Q}^{2}\right)$, effect size $\left(\mathrm{f}^{2}\right)$ and $\mathrm{GoF}$ (Hair et al., 2014) as shown in Table 8: 


\begin{tabular}{|c|c|c|c|c|c|c|c|c|}
\hline $\begin{array}{l}\text { Table } 8 \\
\text { Convergent validity }\end{array}$ & & & & & & & & \\
\hline Indicators & & $\begin{array}{l}\text { Cronbach' Alpha } \\
>0.60\end{array}$ & $\begin{array}{l}\text { Composite } \\
\text { Reliability }>0.70\end{array}$ & $\begin{array}{l}\text { Average } \quad \text { Variance } \\
\text { Extracted }>0.50\end{array}$ & $\mathrm{R}^{2}$ & $\mathrm{Q}^{2}$ & $\mathrm{f}^{2}$ & $\begin{array}{l}\text { Number of } \\
\text { items }\end{array}$ \\
\hline Confirmation & & 0.826 & 0.885 & 0.658 & & & & 4 \\
\hline Habit & & 0.740 & 0.847 & 0.663 & 0.365 & 0.261 & 0.221 & 3 \\
\hline $\begin{array}{l}\text { Intention } \\
\text { Continue to Use }\end{array}$ & to & 0.802 & 0.884 & 0.718 & 0.701 & 0.475 & 0.306 & 3 \\
\hline Perceived Pleasure & & 0.642 & 0.805 & 0.580 & 0.203 & 0.111 & 0.254 & 3 \\
\hline Satisfaction & & 0.819 & 0.892 & 0.733 & 0.664 & 0.463 & 0.702 & 3 \\
\hline Perceived Utility & & 0.613 & 0.788 & 0.565 & 0.317 & 0.167 & 0.465 & 3 \\
\hline
\end{tabular}

The Cronbach's Alpha coefficients varied between 0.613 and 0.826 . Values above 0.60 are considered adequate, therefore, they presented a good result. This median result indicates that the internal consistency of the scales used needs improvement. However, the result does not invalidate the present research, since the scales were tested on a very new object of study, unknown to most of the public (Helms, 1999).

Reliability is the degree to which a set of latent variable indicators is consistent in its measurements. The composite reliability obtained in this study varied between 0.788 and 0.892 indicating that the results were satisfactory in this regard (Hair et al., 2010). For this model, the AVEs (Average Variance Extracted) ranged from 0.565 to 0.733 . Therefore, all latent variables presented average variance extracted greater than 50\%, which meets Chin (1998) criteria for convergent validity.

$\mathrm{R}^{2}$ measures the predictive accuracy of the model, representing the combined effects of endogenous variables on exogenous variables. In the present study, $\mathrm{R}^{2}$ value demonstrated that the model has accuracy and predictive relevance in all constructs.

$\mathrm{Q}^{2}$ evaluates how close the model is to what was expected of it (either the quality of the model's prediction or the accuracy of the adjusted model). According to the criterion used to assess the accuracy of the adjusted model, $\mathrm{Q}^{2}$, the Habit, Intention to Continue to Use, Perceived Pleasure, Satisfaction and Perceived Utility constructs were considered with adequate accuracy, as they had values greater than zero (Hair et al., 2014).

Cohen's $\mathrm{f}^{2}$ is used to estimate the effect size in correlated samples (repeated measurements, longitudinal data, grouped data) for two continuous variables. It evaluates how much each construct is "useful" for model adjustment. Values of $0.02,0.15$ and 0.35 are considered small, medium and large, respectively (Hair et al., 2014).

Goodness of Fit $(\mathrm{GoF})$ is the global adjustment measure, that is, the square root of the multiplication of both the AVE and $\mathrm{R}^{2}$ averages of endogenous variables. In the case of this research, the value of the GoF of $0.542(54.2 \%)$ was considered large enough for the validity of the model in the PLS (Wetzels, Odekerken-Schroder, \& Van Oppen, 2009). 


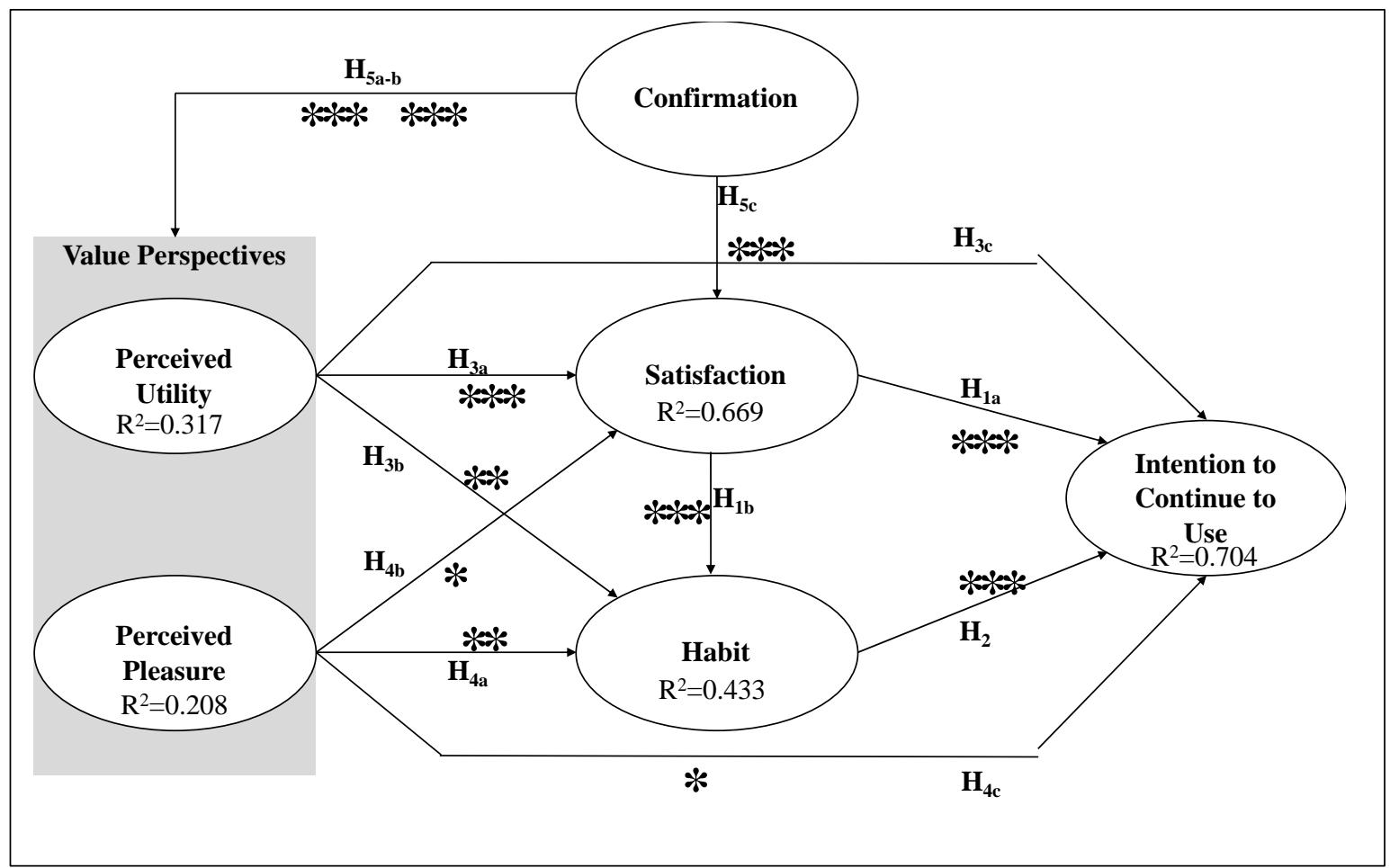

Figure 3 - Proposed Theoretical Model

Note: Significances * $\mathrm{p}<0,05 ;{ }^{* *} \mathrm{p}<0,01$; *** $\mathrm{p}<0,001$

In the practical application of the structural equation modeling for the Proposed Theoretical Model Figure 3, the approach suggests the evaluation of measurement models individually, seeking to verify their validity and consistency and then performing the structural model approach. Other samples composed of elements of the original sample (bootstrapping with $n=320$ ) were taken and the parameters of the model were estimated according to Table 9 (Chin, 1998).

Table 9

Hypotheses test results

\begin{tabular}{|c|c|c|c|c|c|c|}
\hline Hypotheses & Coefficient paths & $\begin{array}{l}\text { Original } \\
\text { sample }(\beta)\end{array}$ & $\begin{array}{l}\text { Bootstrapping } \\
\mathrm{n}=320\end{array}$ & Standard Error & T-Test & P-Values \\
\hline $\mathrm{H}_{1 \mathrm{a}}$ & 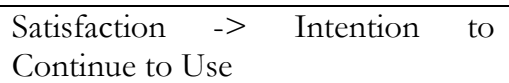 & 0.414 & 0.411 & 0.049 & 8.400 & 0.000 \\
\hline $\mathrm{H}_{1 \mathrm{~b}}$ & Satisfaction -> Habit & 0.342 & 0.348 & 0.071 & 4.844 & 0.000 \\
\hline $\mathrm{H}_{2}$ & $\begin{array}{l}\text { Habit -> Intention to Continue to } \\
\text { Use }\end{array}$ & 0.203 & 0.203 & 0.052 & 3.871 & 0.000 \\
\hline $\mathrm{H}_{3 \mathrm{a}}$ & Perceived Utility -> Satisfaction & 0.263 & 0.261 & 0.058 & 4.520 & 0.000 \\
\hline $\mathrm{H}_{3 \mathrm{~b}}$ & Perceived Utility -> Habit & 0.256 & 0.252 & 0.078 & 3.280 & 0.001 \\
\hline $\mathrm{H}_{3 c}$ & $\begin{array}{l}\text { Perceived Utility -> Intention to } \\
\text { Continue to Use }\end{array}$ & 0.272 & 0.274 & 0.052 & 5.266 & 0.000 \\
\hline $\mathrm{H}_{4 \mathrm{a}}$ & Perceived Pleasure -> Habit & 0.175 & 0.171 & 0.059 & 2.967 & 0.003 \\
\hline $\mathrm{H}_{4 \mathrm{~b}}$ & Perceived Pleasure $->$ Satisfaction & 0.091 & 0.097 & 0.045 & 2.051 & 0.041 \\
\hline $\mathrm{H}_{4 \mathrm{c}}$ & $\begin{array}{l}\text { Perceived Pleasure -> Intention to } \\
\text { Continue to Use }\end{array}$ & 0.111 & 0.110 & 0.048 & 2.312 & 0.021 \\
\hline $\mathrm{H}_{5 \mathrm{a}}$ & Confirmation -> Perceived Utility & 0.563 & 0.566 & 0.039 & 14.586 & 0.000 \\
\hline $\mathrm{H}_{5 \mathrm{~b}}$ & Confirmation $->$ Perceived Pleasure & 0.457 & 0.463 & 0.049 & 9.412 & 0.000 \\
\hline $\mathrm{H}_{5 \mathrm{c}}$ & Confirmation $->$ Satisfaction & 0.587 & 0.587 & 0.046 & 12.700 & 0.000 \\
\hline
\end{tabular}

Note: All hypotheses have been accepted. 


\section{Discussion of results}

Reinforcing previous findings (Bhattacherjee 2001; Baker-Eveleth \& Stone, 2015; Chen, Chen, Lin, \& Chen, 2011; Vatanasombut, Igbaria, Stylianou, \& Rodgers, 2008), hypotheses $\mathbf{H}_{5 \mathrm{a}}$ and $\mathbf{H}_{\mathbf{5 c}}$ obtained the greatest significant relationship among all hypotheses. This is explained by the fact that user satisfaction is determined by the confirmation of their expectations, that is, the more expectations are met, the greater the chance of this being reflected in the perceived utility and satisfaction. For productivity applications, expectations are in relation to increasing efficiency and performance in different aspects of personal, professional and academic life.

The $\mathbf{H}_{3 \mathrm{~b}}$ hypothesis, described in the relationship between "Perceived Utility" and "Habit", presented a strong relationship between variables, which can be explained by the perception of performance and positive utility, which increases the tendency to use the system frequently, reflecting in habit.

The hypotheses $\mathbf{H}_{4 \mathrm{~b}}$, described in the casual relationship of "Perceived pleasure" and "Satisfaction", in spite of being significant path $(\mathrm{p}=0,041)$, and $\mathbf{H}_{4 \mathrm{c}}$, provide evidence that perceived pleasure is a critical element in the consumers' decisions to continue to use productivity applications, given that most of the scientific literature supports the argument that the intention to continue to use apps is driven by hedonic values. A possible reason for this result is the fact that productivity applications require effort and demand user time and hedonic consumption does not bring with it the negative sense of hard work and difficult to be carried out (Babin et al., 1994).

Hedonic products and services can play an important role in consumers' lives by providing them with pleasure and escape from their fantasies and the consumer may only be seeking sensory-emotional stimuli (Chiu et al., 2014; Holbrook \& Hirschman, 1982). In the case of productivity applications, its main objective is the achievement of goals, financial management, personal organization, among others, which does not necessarily reflect the pleasure of escape, since the focus of these applications is the routine itself. This can generate frustration and the opposite of the feeling of satisfaction and, consequently, not influence the intention to continue using productivity apps.

In addition, there is a comparative decision process between "wanting" (hedonic) versus "duty" (utilitarian). Wanting goods are often preferred in choices made in sequence and bring immediate benefits with no visible negative side. Goods of duty are chosen when they are presented simultaneously with goods of wanting, they have their benefits seen after use (Voss, Spangenberg, \& Grohmann, 2003). As we can infer, the choice of productivity applications is based on "duty".

The objective of the paper was achieved, which sought to understand the role of user value perspectives (perceived utility and perceived pleasure) in the intention to continue to use mobile productivity applications.

The applied model was considered valid, since all direct relationships were supported with significant results in the tested causal relationships and were validated based on the theoretical aspects presented. Thus, the results validate the model and confirm that the selected constructs have considerable explanatory power when adapted to assess the intention to continue to use mobile productivity applications.

It was understood that, in productivity apps, the hedonic characteristic should be observed carefully, and that this type of app has greater identification with perceived utility characteristics and confirmation of expectations, by its very nature.

The literature points out that consumers perceive several benefits resulting from the use of productivity apps, such as practicality, increased efficiency and productivity. It was noticed that the main difficulties related to the use of productivity apps are memory and cell phone storage, need for discipline, limitations 
of free versions of the apps, number of in-app ads, need for internet access and time needed to allocate information in the system.

This study provides implications, both theoretical and practical, related to the intention to continue using mobile productivity applications. The results are useful for developers and application companies, as they bring information related to the behavior of their consumers.

It is observed the importance of the variables Confirmation, Perceived Utility and Habit as antecedent factors of the intention to continue to use apps. Developers should, therefore, emphasize the utilitarian, confirmatory characteristics that favor the creation and maintenance of the usage habit, in order to improve the users' productivity and, thus, increase the intention to continue using the applications.

Therefore, it is important to align the user's expectations about the application before the first contact. This can be done at first in the app store, with a clear description of the application features, the next moment would be to make all the necessary information available on the initial screen. The application must provide a simple journey with features that help the consumer to achieve goals and objectives, it must also provide high-value content that meets expectations and can be accessed and digested quickly. In addition, navigation must be clear, task-focused, and consistent across the application.

Most respondents demonstrated forgetting to use mobile productivity applications after some time of use, for several reasons: strong competition between applications or even lack of interest. This behavior must be considered by the application companies and can be avoided or reduced through, for example, push notifications, relevant and timely messages on the device that remind the user to use the application. With thousands of productivity applications available on the market and a high rate of users forgetting applications, it is necessary for developers and application companies to understand which factors influence the intention to continue to use, given the high profitability and competitiveness of this category.

Another possibility are campaigns that reinforce the use of applications already installed on the device. The marketing strategies of companies usually focus on winning new consumers, however, campaigns for re-engagement are also very important, for user retention.

The "perceived pleasure" construct, although significant, had a very small impact on the intention to continue to use. Therefore, application designers and developers should make no effort to reinforce the hedonic value and hedonic user experiences. This can avoid wasting resources when the objective is to increase the intention to continue to use.

Many users also pointed out as a barrier to the use of applications the lack of storage space on the cell phone. By incorporating hedonic features, applications have functionality related not only to utility, but also to pleasure. That is, they are probably heavier and more likely to be slow or crash the device, generating frustration for the user and not meeting customers utility expectations. Ideally, applications should be lightweight, do not need an internet or mobile network and deliver well the basics.

We also believe that a relevant contribution of this study is the identification of the factors that precede the intention to use apps. Especially in the current social context, in which the social confinement motivated by the pandemic caused by COVID-19, makes a large part of the face-to-face commercial transactions impossible, the use of apps becomes even more important for the economy and for the maintenance of public health.

Regarding the limitations of this research, the method of data collection was convenience sampling, a fact that limits the generalization of research results. Furthermore, female respondents constituted almost $71 \%$ of our sample, which does not represent the gender distribution in the population. According to data from the Instituto Brasileiro de Geografia e Estatística - IBGE (2019), the Brazilian population consists of $48.3 \%$ of men and $51.7 \%$ of women. Future studies can therefore use a sample with gender 
participation closer to reality. In this research, no analysis of mediations (indirect relationships) was performed, since the model was considered valid in all direct relationships.

\section{References}

Allen, M. W., \& Ng, S. H. (1999). The direct and indirect influences of human values on product ownership. Journal of Economic Psychology, 20(1), 5-39. doi: 10.1016/S0167-4870(98)00041-5

Anderson, E. W., Fornell, C., \& Lehmann, D. R. (1994). Customer Satisfaction, Market Share, and Profitability: Findings from Sweden. Journal of Marketing, 58(3), 53-66. doi: 10.2307/1252310

Andersson, P., \& Engelberg, E. (2006). Affective and rational consumer choice modes: The role of intuition, analytical decision-making, and attitudes to money (No. 2006:13). Retrieved from Stockholm School of Economics website: https://ideas.repec.org/p/hhb/hastba/2006_013.html

Arruda Filho, E. J., Cabusas, J., \& Dholakia, N. (2010). Social behavior and brand devotion among iPhone innovators. International Journal of Information Management, 30(6), 475-480. doi: 10.1016/j.ijinfomgt.2010.03.003

Azfar, A., Choo, K.-K. R., \& Liu, L. (2016). Android mobile VoIP apps: A survey and examination of their security and privacy. Electronic Commerce Research, 16(1), 73-111. doi: 10.1007/s10660-015-9208-1

Babin, B. J., Darden, W. R., \& Griffin, M. (1994). Work and/or Fun: Measuring Hedonic and Utilitarian Shopping Value. Journal of Consumer Research, 20(4), 644-656. doi: 10.1086/209376

Baker-Eveleth, L., \& Stone, R. W. (2015). Usability, expectation, confirmation, and continuance intentions to use electronic textbooks: Behaviour \& Information Technology: Vol 34, No 10. Behaviour \& Information Technology, 34(10), 992-1004. doi: 10.1080/0144929X.2015.1039061

Bardhi, F., \& Arnould, E. J. (2005). Thrift shopping: Combining utilitarian thrift and hedonic treat benefits. Journal of Consumer Behaviour, 4(4), 223-233. doi: 10.1002/cb.12

Barnes, S. (2011). Understanding use continuance in virtual worlds: Empirical test of a research model. Information \& Management, 48(8), 313-319. doi: 10.1016/j.im.2011.08.004

Batra, R., \& Ahtola, O. T. (1991). Measuring the hedonic and utilitarian sources of consumer attitudes. Marketing Letters, 2(2), 159-170. doi: 10.1007/BF00436035

Bauer, H. H., Reichardt, T., Barnes, S. J., \& Neumann, M. M. (2005). Driving Consumer Acceptance of Mobile Marketing: A Theoretical Framework and Empirical Study. Journal of Electronic Commerce Research, 6(3), 181-192.

Bertolini, D. N. P., \& Simonetti, J. P. (2014). O gênero masculino e os cuidados de saúde: A experiência de homens de um centro de saúde. Escola Anna Nery, 18(4), 722-727. doi: 10.5935/1414-8145.20140103

Bertschek, I., \& Nieble, T. (2016). Mobile and More Productive? Firm-Level Evidence on the Productivity Effects of Mobile Internet Use. Telecommunications Policy, 40(9), 888-898. doi: 10.1016/j.telpol.2016.05.007

Bhattacherjee, A. (2001). Understanding Information Systems Continuance: An ExpectationConfirmation Model. MIS Quarterly, 25(3), 351-370. doi: 10.2307/3250921

Bhattacherjee, A., Limayem, M., \& Cheung, C. M. K. (2012). User switching of information technology: A theoretical synthesis and empirical test. Information and Management, 49(7-8), 327-333. doi: 10.1016/j.im.2012.06.002

Brown, S. A., \& Venkatesh, V. (2005). Model of adoption of technology in households: A baseline model test and extension incorporating household life cycle. MIS Quarterly, 29(3), 399-426. doi: $10.2307 / 25148690$ 
Chen, S.-C., Chen, H.-H., Lin, M.-T., \& Chen, Y.-B. (2011). A conceptual model to undersant the effects of perception on the continuance intention in Facebook. Australian Journal of Business and Management Research, 1(8), 29-34.

Childers, T., Carr, C., Peck, J., \& Carson, S. (2001). Hedonic and Utilitarian Motivations for Online Retail Shopping Behavior. Journal of Retailing, 77(4), 511-535. doi: 10.1016/S0022-4359(01)00056-2

Chin, W. W. (1998). The partial least squares approach for structural equation modeling. In G. A. Marcoulides, Modern methods for business research (pp. 295-336). Mahwah, NJ, US: Lawrence Erlbaum Associates Publishers.

Chiu, C. M., Wang, E. T., Fang, Y. H., \& Huang, H. Y. (2014). Understanding customers' repeat purchase intentions in B2C e-commerce: The roles of utilitarian value, hedonic value and perceived risk-Chiu2014-Information Systems Journal-Wiley Online Library. Information Systems Journal, 24(1), 85-114. doi: 10.1111/j.1365-2575.2012.00407.x

Chou, S.-W., \& Hsu, C.-S. (2016). Understanding online repurchase intention: Social exchange theory and shopping habit. Information Systems and E-Business Management, 14(1), 19-45. doi: 10.1007/s10257-0150272-9

Davis, F. D. (1989). Perceived Usefulness, Perceived Ease of Use, and User Acceptance of Information Technology. MIS Quarterly, (13), 319-340. doi: 10.2307/249008

DeSarbo, W. S., Jedidi, K., \& Sinha, I. (2001). Customer value analysis in a heterogeneous market | Request PDF. Strategic Management Journal, 22(9), 845-857. doi: 10.1002/smj.191

Dorsch, M. J., Grove, S. J., \& Darden, W. R. (2000). Consumer intentions to use a service category. Journal of Services Marketing, 14(2), 92-117. doi: 10.1108/08876040010309220

Hair, J. F., Hult, G., Tomas, M., Ringle, C., \& Sarstedt, M. (2010). Multivariate Data Analysis: A Global Perspective. New Jersey: Pearson Prentice Hall.

Hair, J. F., Hult, G., Tomas, M., Ringle, C., \& Sarstedt, M. (2014). A Primer on Partial Least Squares Structural Equation Modeling (PLS-SEM). Retrieved from https://us.sagepub.com/en-us/nam/a-primer-on-partialleast-squares-structural-equation-modeling-pls-sem/book244583

Helms, J. E. (1999). Another meta-analysis of the White Racial Identity Attitude Scale's Cronbach alphas: Implications for validity. Measurement and Evaluation in Counseling and Development, 32(3), 122-137. doi: 10.1080/07481756.1999.12068979

Hernandez, J. M. C. (2009). Foi Bom para Você? Uma Comparação do Valor Hedônico de Compras Feitas em Diferentes Tipos de Varejistas. RAM - Revista de Administração Mackenzie, 10(2), 11-30.

Holbrook, M. B., \& Corfman, K. P. (1985). Quality and Value in the Consumption Experience: Phaedrus Rides Again. In J. Jacoby \& Jerry. C. Olson, Perceived Quality: How Consumers View Stores and Merchandise (pp. 31-57). Lexington, MA: Lexington Books.

Holbrook, M. B., \& Hirschman, E. C. (1982). The experiential aspects of consumption: Consumer fantasies, feelings, and fun. Journal of Consumer Research, 9(2), 132-140. doi: 10.1086/208906

Hsiao, C.-H., Chang, J.-J., \& Tang, K.-Y. (2016). Exploring the influential factors in continuance usage of mobile social Apps: Satisfaction, habit, and customer value perspectives. Telematics and Informatics, 33 , 342-355. doi: 10.1016/j.tele.2015.08.014

Hsu, C.-L., \& Lin, J. C.-C. (2016). Effect of perceived value and social influences on mobile app stickiness and in-app purchase intention. Technological Forecasting and Social Change, 108(C), 42-53. doi: 10.1016/j.techfore.2016.04.012 
IBGE (2019). Conheça o Brasil - População Quantidade de homens e mulheres. Retrieved February 29, 2020, from https://educa.ibge.gov.br/jovens/conheca-o-brasil/populacao/18320-quantidade-dehomens-e-mulheres.html

Islam, Z., Low, P. K. C., \& Hasan, I. (2013). Intention to use advanced mobile phone services (AMPS). Management Decision, 51(4), 824-838. doi: 10.1108/00251741311326590

Jones, M. A., Mothersbaugh, D. L., \& Beatty, S. E. (2002). Why customers stay: Measuring the underlying dimensions of services switching costs and managing their differential strategic outcomes. Journal of Business Research, 55(6), 441-450. doi: 10.1016/S0148-2963(00)00168-5

Jones, M., Reynolds, K., \& Arnold, M. (2006). Hedonic and Utilitarian Shopping Value: Investigating Differential Effects on Retail Outcomes. Journal of Business Research, 59(9), 974-981. doi: 10.1016/j.jbusres.2006.03.006

Kim, H. -W., Chan, K. C., \& Gupta, S. (2007). Value-based Adoption of Mobile Internet: An empirical investigation. Decision Support Systems, 43(1), 111-126. doi: 10.1016/j.dss.2005.05.009

Kim, Hee-Woong, Gupta, S., \& Koh, J. (2011). Investigating the intention to purchase digital items in social networking communities: A customer value perspective. Information and Management, 48(6), 228234. doi: $10.1016 /$ j.im.2011.05.004

Kim, S. S., \& Malhotra, N. K. (2005). A Longitudinal Model of Continued IS Use: An Integrative View of Four Mechanisms Underlying Postadoption Phenomena. Management Science, 51(5), 741-755. doi: $10.1287 / \mathrm{mnsc} .1040 .0326$

Kim, S. S., Malhotra, N. K., \& Narasimhan, S. (2005). Two competing perspectives on automatic use: A theoretical and empirical comparison. Information Systems Research, 16(4), 418-432. doi: 10.1287 /isre. 1050.0070

Lee, E.-J., \& Overby, J. W. (2004). Creating Value For Online Shoppers: Implications For Satisfaction and Loyalty. Journal of Consumer Satisfaction, Dissatisfaction and Complaining Behavior, AP-06(17), 54-67.

Limayem, M., \& Hirt, S. G. (2003). Force of Habit and Information Systems Usage: Theory and Initial Validation. Journal of the Association for Information Systems, 4, 65-97. doi: 10.17705/1 jais.00030

Limayem, M., Hirt, S. G., \& Cheung, C. M. K. (2007). How Habit Limits the Predictive Power of Intention: The Case of Information Systems Continuance. MIS Quarterly, 31(4), 705-737. doi: $10.2307 / 25148817$

Luo, W., \& Lee, Y.-C. (2015). Examining Customer's Continuance Intention Toward Mobile IM Service from the Perspectives of Interaction and Network Externalities. Information, 18(1), 51-62.

Malhotra, N. K. (2014). Essentials of Marketing Research: A Hands-On Orientation. New York: Pearson Education.

Mano, H., \& Oliver, R. L. (1993). Assessing the Dimensionality and Structure of the Consumption Experience: Evaluation, Feeling, and Satisfaction. Journal of Consumer Research, 20(3), 451. doi: $10.1086 / 209361$

Oliver, R. L. (1999). Whence Consumer Loyalty? Journal of Marketing, 63, 33-44. doi: 10.2307/1252099

Pöyry, E., Parvinen, P., \& Malmivaara, T. (2013). Can we get from liking to buying?Behavioral differences in hedonic and utilitarian Facebook usage. Eletronic Commerce Research and Applications, 12(4), 224-235. doi: 10.1016/j.elerap.2013.01.003

Rauyruen, P., Miller, K. E., \& Groth, M. (2009). B2B services: Linking service loyalty and brand equity. Journal of Services Marketing, 23(3), 175-186. doi: 10.1108/08876040910955189

Ringle, C., Da Silva, D., \& Bido, D. (2015). Structural equation modeling with the SmartPLS. Brazilian Journal of Marketing, 13 (2). 
Rogers, E. M. (1995). The Diffusion of Innovations (4th ed.). New York: The Free Press.

Shiau, W.-L., \& Luo, M. M. (2013). Continuance intention of blog users: The impact of perceived enjoyment, habit, user involvement and blogging time. Behaviour \& Information Technology, 32(6), 570-583. doi: 10.1080/0144929X.2012.671851

Statista. (2018). Number of mobile app downloads worldwide in 2017, 2018 and 2022 (in billions). Retrieved July 15, 2019, from Statista website: https://www.statista.com/statistics/271644/worldwidefree-and-paid-mobile-app-store-downloads/

Thong, J. Y. L., Hong, S.-J., \& Tam, K. Y. (2006). The effects of post-adoption beliefs on the expectationconfirmation model for information technology continuance. International Journal of Human-Computer Studies, 64(9), 799-810. doi: 10.1016/j.ijhcs.2006.05.001

Turel, O., Serenko, A., \& Bontis, N. (2010). User acceptance of hedonic digital artifacts: A theory of consumption values perspective. Information \& Management, 47(1), 53-59. doi: 10.1016/j.im.2009.10.002

Van Der Heijden, H. (2004). User Acceptance of Hedonic Information Systems. MIS Quarterly, 28(4), 695-704. doi: 10.2307/25148660

Vatanasombut, B., Igbaria, M., Stylianou, A. C., \& Rodgers, W. (2008). Information systems continuance intention of web-based applications customers: The case of online banking. Information \& Management, 45(7), 419-428. doi: 10.1016/j.im.2008.03.005

Verplanken, B., \& Wood, W. (2006). Interventions to break and create consumer habits. Journal of Public Policy and Marketing, 25(1), 90-103. doi: 10.1509/jppm.25.1.90

Voropanova, E. (2015). Conceptualizing smart shopping with a smartphone: Implications of the use of mobile devices for shopping productivity and value. The International Review of Retail, Distribution and Consumer Research, 25(5), 529-550. doi: 10.1080/09593969.2015.1089304

Voss, K. E., Spangenberg, E. R., \& Grohmann, B. (2003). Measuring the Hedonic and Utilitarian Dimensions of Consumer Attitude. Journal of Marketing Research, 40(3), 310-320. doi: 10.1509/jmkr.40.3.310.19238

Wetzels, M., Odekerken-Schroder, G., \& Van Oppen, C. (2009). Using PLS Path Modeling for Assessing Hierarchical Construct Models: Guidelines and Empirical Illustration. MIS Quarterly, 33(1), 177-195. doi: $10.2307 / 20650284$

Zanna, M. P., \& Rempel, J. K. (1988). Attitudes: A new look at an old concept. In D. Bar-Tal \& A. W. Kruglanski, The social psychology of knowledge (pp. 315-334). Cambridge: Cambridge University Press.

Zeithaml, V. (1988). Consumer Perceptions of Price, Quality and Value: A Means-End Model and Synthesis of Evidence. Journal of Marketing, 52(3), 2-22. doi: 10.1177/00222429880520030 